\title{
Strategi Kepala Sekolah Dalam Pemasaran Jasa Pendidikan di Lembaga Pendidikan Baru Pada Era Marketing 4.o (Studi Kasus di SMK BP Subulul Huda)
}

\author{
Aris Nurbawani \\ IAIN Ponorogo, Indonesia \\ arisnurbawani@gmail.com
}

DOI: https://doi.org/10.21154/sajiem.v2i1.41

\begin{abstract}
In 2016, the government promoted the revitalization of vocational high schools (SMK). In East Java, the vocational high school revitalization was accelerated with the target of achieving a percentage of the ratio between SMK and SMA (senior high schools) of 70:30. The East Java provincial government should implement a moratorium on the establishment of SMA and facilitate the process of changing the function of SMA to SMK. However, inviting residents to attend vocational schools is not an easy matter, in fact there are still many vocational schools that are devoid of enthusiasts. The headmaster must be right in choosing a marketing strategy for educational services so that gets students as expected. Qualitative research on the headmaster's strategy in marketing educational services at new educational institutions is important to do in order to get a marketing model that is relevant to the times. This research data collection using interview techniques, observation, and documentation. The results of this study are first, the headmaster's strategy in marketing (SMK BP Subulul Huda) is based on the strategic policy of the islamic boarding school foundation, namely a forward integration strategy. To follow up on the policy, the headmaster prepared a marketing plan using market segmentation, targeting, and positioning strategies. Second, marketing implementation is carried out by applying the marketing mix $(7 P)$. Third, the headmaster develops educational services that are human-oriented and a marketing approach that is applied using offline and online interactions that are relevant to the Marketing 4.0.
\end{abstract}

\begin{abstract}
Abstrak
Pada tahun 2016, pemerintah menggalakkan revitalisasi sekolah menengah kejuruan dalam rangka peningkatan kualitas dan daya saing sumber daya manusia Indonesia. Di Jawa Timur, pada tahun 2017 melakukan percepatan revitalisasi sekolah menengah kejuruan tersebut dengan target mencapai persentase perbandingan SMK dan SMA sebesar 70:30. Melalui peraturan Gubernur, diputuskan bahwa pemerintah Provinsi Jawa Timur melakukan moratorium pendirian SMA dan mempermudah proses alih fungsi SMA menjadi SMK. Namun, mengajak warga agar sekolah di SMK bukan perkara mudah, faktanya masih dijumpai SMK yang sepi peminat khususnya SMK di kawasan terjauh dan terdepan, bahkan tidak hanya di pedesaan saja, di kota besar juga ada SMK yang kekurangan murid. Kepala sekolah harus tepat dalam memilih strategi pemasaran jasa pendidikan agar sekolah yang dikelolanya mendapatkan murid sesuai
\end{abstract}


harapan. Penelitian kualitatif tentang strategi kepala sekolah dalam pemasaran jasa pendidikan pada lembaga pendidikan baru pada era Marketing 4.0 penting untuk dilakukan agar mendapatkan sebuah model pemasaran yang relevan dengan perkembangan zaman. Pengumpulan data penelitian ini menggunakan teknik wawancara, pengamatan, dan dokumentasi. Temuan penelitian ini pertama, strategi kepala sekolah dalam pemasaran SMK BP Subulul Huda didasari oleh kebijakan strategis Yayasan Pondok Pesantren yaitu strategi pertumbuhan integrasi ke depan. Untuk menindaklanjuti kebijakan tersebut kepala sekolah menyusun perencanaan pemasaran dengan menggunakan strategi segmentasi pasar, targeting, dan positioning. Kedua, implementasi pemasaran dilakukan dengan menerapkan bauran pemasaran $7 \mathrm{P}$. Ketiga, kepala sekolah membangun produk/jasa pendidikan yang berorientasi pada manusia (mencerminkan nilai-nilai kemanusiaan) dan pendekatan pemasaran yang diterapkan menggunakan interaksi offline dan online yang relevan dengan era Marketing 4.o.

Keyword: strategi kepala sekolah; pemasaran jasa pendidikan; marketing 4.0; pemasaran lembaga pendidikan baru

\section{Pendahuluan}

Kepala sekolah berperan sangat penting bagi keberhasilan dan keberlanjutan sebuah lembaga pendidikan yang dikelolanya. Seorang kepala sekolah minimal harus berfungsi sebagai edukator, manajer, administrator, supervisor, leader, inovator, dan motivator (EMASLIM) dalam mengelola sekolah yang dipimpinnya ${ }^{1}$ Salah satu peran kepala sekolah dalam menjalankan fungsinya tersebut adalah mengelola kegiatan pemasaran jasa pendidikan untuk lembaga pendidikan yang dipimpinnya dengan menggunakan strategi yang khas. Robbins dan Coulter (2007) mendefinisikan strategi sebagai keputusan dan tindakan yang menentukan kinerja jangka panjang sebuah organisasi ${ }^{2}$. Sedemikian pentingnya strategi bagi keberhasilan masa depan sebuah organisasi, maka sangat menarik untuk meneliti strategi seorang kepala sekolah.

Kegiatan pemasaran kini tidak hanya dimonopoli oleh lembaga bisnis yang berorientasi pada profit/laba (keuntungan dalam bentuk uang). Sekarang, setiap lembaga profesional sudah lazim menerapkan kegiatan pemasaran, termasuk pada lembaga pendidikan. Lembaga pendidikan merupakan lembaga non-profit, yang tentu saja memiliki ciri khas yang berbeda dengan kegiatan pemasaran secara umum pada lembaga bisnis yang berorientasi pada profit. Sejauh ini, peneliti belum menemukan penelitian yang fokus pada pemasaran jasa pendidikan pada lembaga pendidikan yang baru. Kebanyakan penelitian yang diketahui peneliti, pelaksanaan penelitian dilakukan di lembaga organisasi yang tidak baru, seperti penelitian yang dilakukan oleh Kuni Fathonah (2016) dengan studi kasus di MAN I Sragen. Hasil penelitian Kuni Fathonah menjelaskan bahwa strategi pemasaran jasa pendidikan yang dilakukan MAN I Sragen I Sragen adalah: (a). Pemasaran secara langsung, yaitu dengan pemanfaatan IT, media cetak maupun elektronik. (b). Pemasaran tidak langsung yaitu dengan mengadakan sosialisasi ke Sekolah Menengah Pertama maupun Madrasah Tsanawiyah dan kepada masyarakat. ${ }^{3}$ Penelitian terdahulu lainnya adalah penelitian yang dilakukan oleh Syafi'ur Rahman (2015) dengan studi kasus di MAN 3 Kota Cirebon. Syafi'ur Rahman (2015) menjelaskan hasil penelitiannya bahwa implementasi pemasaran di MAN 3 Kota Cirebon dilakukan dalam dua kegiatan utama yaitu merumuskan strategi dan taktik pemasaran. Merumuskan strategi persaingan diwujudkan dengan cara mengidentifikasi segmentasi pasar, targeting dan positioning. Sedangkan merumuskan taktik pemasaran diwujudkan dengan menerapkan bauran pemasaran. Bauran pemasaran diwujudkan dengan menghasilkan produk-produk yang berkualitas, menonjolkan

${ }^{1}$ E. Mulyasa, Menjadi Kepala Sekolah Profesional (Bandung: PT. Remaja Rosdakarya, 2006).

${ }^{2}$ Bilson Simamora, Pemasaran Strategik, 1 ed. (Tangerang Selatan: Universitas Terbuka, 2013).

${ }^{3}$ Kuni Fathonah, "Strategi Pemasaran Jasa Pendidikan Dalam Meningkatkan Pelayanan Pendidikan di MAN I Sragen” (Surakarta, IAIN Surakarta, 2016). 
letak geografis MAN 3 Kota Cirebon yang sangat strategis, menentukan harga yang bersaing dengan lembaga pendidikan lain, dan juga melaksanakan promosi. ${ }^{4}$

Pada tahun 2017, Gubernur Jawa Timur mengeluarkan peraturan yang bertujuan untuk menindaklanjuti Instruksi Presiden Nomor 9 Tahun 2016 tentang Revitalisasi Sekolah Menengah Kejuruan Dalam Rangka Peningkatan Kualitas dan Daya Saing Sumber Daya Manusia Indonesia. Peraturan Gubernur yang dimaksud adalah Peraturan Gubernur Nomor 22 Tahun 2017 tentang Percepatan Revitalisasi Sekolah Menengah Kejuruan di Provinsi Jawa Timur. Peraturan Gubernur tersebut bertujuan untuk menindaklanjuti Rencana Pembangunan Jangka Menengah Daerah Provinsi Jawa Timur untuk mencapai persentase perbandingan SMK dan SMA sebesar 70:30. Dalam peraturan Gubernur tersebut memutuskan bahwa pemerintah Provinsi Jawa Timur menghentikan pendirian SMA untuk sementara waktu (moratorium) dan mempermudah proses alih fungsi SMA menjadi SMK. ${ }^{5}$ Peraturan Gubernur tersebut merupakan angin segar bagi pegiat pendidikan untuk mendirikan SMK karena akan mendapatkan kemudahan dari pemerintah Jawa Timur. Namun, mengubah keinginan warga untuk lebih memilih sekolah di SMK daripada di SMA bukan perkara mudah dan disisi yang lain seiring waktu tentunya semakin banyak jumlah SMK yang tentu saja dapat memunculkan masalah baru bagi pengelola SMK, seperti dijumpai adanya SMK yang sepi peminat. Menurut Syaiful Rachman Kepala Dinas Pendidikan Jawa Timur, keberadaan SMK sepi peminat mayoritas berada di kawasan terjauh dan terdepan semisal di kepulauan dan di pedesaan, bahkan tidak hanya di pedesaan di kota besar juga ada yang kekurangan murid. Masih menurut Syaiful Rachman, bahwa ada laporan di SMKN 12 Surabaya juga kekurangan murid, karena jurusan yang disediakan tidak diminati lagi. ${ }^{6}$ Berdasarkan fakta tersebut, seorang kepala SMK baru memiliki tantangan yang lebih berat. Seorang kepala sekolah harus membuat kebijakan yang tepat sejak awal, termasuk kebijakan dalam hal pemasaran jasa pendidikannya sehingga sekolah bisa mendapatkan murid sesuai yang diharapkannya. Demikian juga kepala Sekolah Menengah Kejuruan Berbasis Pesantren (SMK BP) Subulul Huda di Kebonsari, Kabupaten Madiun, tentu memiliki strategi khusus dalam membuat kebijakan untuk lembaganya. SMK BP Subulul Huda merupakan sekolah kejuruan yang baru saja berdiri (mulai beroperasi pada tahun 2017) dan berbasis pesantren. Peneliti tertarik untuk mengetahui strategi kepala sekolah dalam mengelola SMK dari awal berdiri hingga mendapatkan murid yang tentunya mengalami berbagai kendala. Pada awal pendirian SMK merupakan masa-masa yang krusial karena kepala sekolah dituntut untuk bisa mendapatkan murid di tengah-tengah sekolah lain yang kesulitan mendapatkan murid.

Kepala sekolah yang menginginkan lembaga pendidikan yang dipimpinnya sukses di masa depan, maka melakukan pemasaran jasa pendidikan adalah suatu keniscayaan. Indradjaja dan Karno (2007) menegaskan bahwa pemasaran jasa pendidikan sangat diperlukan untuk: (1) meyakinkan pelanggan dan masyarakat bahwa keberadaan sekolah masih eksis dan relevan dengan kebutuhan mereka, (2) mengenalkan dan memahamkan pelanggan dan masyarakat terhadap jenis jasa pendidikan yang dilakukan oleh pihak sekolah sehingga mereka tidak meninggalkannya7. Pada tahun 2017, Bapak Pemasaran Modern Dunia Philip Kotler dan Bapak Pemasaran Indonesia Hermawan Kartajaya mengenalkan istilah Marketing 4.0 melalui peluncuran sebuah buku "Marketing 4.0 Moving from Traditional to Digital". Marketing 4.0 tersebut merupakan sebuah jawaban di bidang pemasaran untuk menjawab tantangan dan keniscayaan atas perkembangan teknologi yang memengaruhi perekonomian dunia, khususnya

\footnotetext{
${ }^{4}$ Syafi'ur Rahman, "Strategi Pemasaran Jasa Pendidikan Madrasah Dalam Meningkatkan Kompetensi Lulusan (Studi Analisis di MAN 3 Kota Cirebon)” (UIN Sunan Kalijaga, 2015).

5 "Peraturan Gubernur Nomor 22 Tahun 2017 tentang Percepatan Revitalisasi Sekolah Menengah Kejuruan di Provinsi Jawa Timur," 2017.

${ }^{6}$ Fatkhurohman Taufik, "SMA dan SMK yang Sepi Peminat, Ini yang Akan Dilakukan Pemerintah," Berita, Suarasurabaya.net, 11 Juli 2017, https://www.suarasurabaya.net/kelanakota/2017/SMA-dan-SMKyang-Sepi-Peminat-Ini-yang-Akan-Dilakukan-Pemerintah/.

${ }^{7}$ David Wijaya, Pemasaran Jasa Pendidikan (Jakarta: Salemba Empat, 2012).
} 
negara-negara berkembang seperti Indonesia yang sedang bergerak menuju ekonomi digital ${ }^{8}$. Inovasi digital diharapkan mampu membawa setiap negara menuju pada kemakmuran yang berkesinambungan sebagaimana yang dinyatakan oleh OECD (Organization for Economic Cooperation and Development) ${ }^{9}$. Seiring dunia masuk pada era Marketing 4.0 ini, peneliti juga tertarik bagaimana era Marketing 4.0 ini memengaruhi strategi kepala sekolah dalam pemasaran jasa pendidikan lembaganya.

\section{Metodologi Penelitian}

Penelitian ini menggunakan pendekatan kualitatif. Jenis penelitian ini adalah studi kasus sehingga peneliti hadir langsung ke lapangan (SMK BP Subulul Huda) untuk mengumpulkan data. Data primer didapatkan dengan menggunakan teknik wawancara, pengamatan langsung, dan memanfaatkan dokumen yang ada. Pengumpulan data primer dilakukan melalui wawancara langsung dengan kepala SMK BP Subulul Huda yaitu Bapak Muchtim Humaidi, M.IRKH. Teknik analisis data menggunakan model analisis Miles dan Huberman. Penelitian ini bertujuan untuk mendeskripsikan bagaimana strategi kepala sekolah SMK BP Subulul Huda dalam merencanakan dan mengimplementasikan pemasaran jasa pendidikan di lembaganya pada saat awal-awal pendiriannya, dan bagaimana relevansi strategi pemasaran tersebut dengan era Marketing 4.o.

\section{Profil SMK BP Subulul Huda}

SMK BP Subulul Huda terletak di Jl. Anggur RT o8 RW o2 Kembangsawit, Desa Rejosari, Kecamatan Kebonsari, Kabupaten Madiun, Propinsi Jawa Timur. SMK BP Subulul Huda didirikan pada tanggal 4 September 2017 (Nomor SK Pendirian 188.4/5282/101.3/2017) dan memiliki izin operasional pada 13 September 2017 (Nomor SK Izin Operasional 421.5/5510.32/101.3/2017). SMK BP Subulul Huda berada di bawah naungan Yayasan Pendidikan dan Pondok Pesantren (Ponpes) Subulul Huda. ${ }^{10}$ Berikut ini adalah pimpinan utama SMK BP Subulul Huda:

Tabel 1. Pimpinan SMK BP Subulul Huda

\begin{tabular}{|c|l|l|}
\hline NO & \multicolumn{1}{|c|}{ NAMA } & \multicolumn{1}{c|}{ JABATAN } \\
\hline $\mathbf{1}$ & H. Muhammad Tafrikhan, M.Si & Ketua Yayasan Pendidikan \& Ponpes Subulul Huda \\
\hline $\mathbf{2}$ & KH. Achmad Mizan Basyari & Pengasuh Ponpes Subulul Huda \\
\hline 3 & Muchtim Humaidi, M.IRKH & Kepala SMK-BP Subulul Huda \\
\hline
\end{tabular}

\section{Visi SMK BP Subulul Huda}

SMK BP Subulul Huda Kembangsawit memiliki visi sebagai berikut: ${ }^{11}$

"Terwujudnya layanan pendidikan unggul berbasis pesantren mampu mencetak lulusan yang terampil, inovatif, kreatif, dedikatif, kompetitif, dan berwawasan global berbasiskan ilmu dan adab."

\section{Strategi Perencanaan Pemasaran Jasa Pendidikan di SMK BP Subulul Huda}

Sebelum menentukan aktivitas pemasaran lebih jauh, kepala SMK BP Subulul Huda melakukan identifikasi pasar yang akan ditarget dengan mempertimbangkan apa saja yang dibutuhkan oleh pasar. Dalam hal penentuan jurusan yang akan dibuka, sebenarnya yang diharapkan oleh pihak provinsi adalah jurusan otomotif, pertanian atau teknik pengolahan hasil pertanian, namun kepala SMK BP Subulul Huda tidak berani membuka jurusan tersebut karena

\footnotetext{
${ }^{8}$ Sigit Kurniawan, "Memahami Marketing 4.o dalam Konteks Ekonomi Digital," diakses 5 September 2018, http://marketeers.com/mengenal-marketing-4-o-dalam-konteks-ekonomi-digital/.

${ }^{9}$ Kurniawan.

10 "Profil SMK BP Subulul Huda," 2019.

" "Profil SMK BP Subulul Huda."
} 
beliau memprediksi bahwa yang akan mendaftar itu kebanyakan wanita dan perkembangan zaman mengarah ke hal-hal yang terkait dengan teknologi IT (information technology). ${ }^{12}$

Pendirian SMK BP Subulul Huda memang dilakukan dalam rangka menampung alumni SMP IT Subulul Huda yang mayoritas adalah wanita. SMP IT Subulul Huda adalah Sekolah Menengah Pertama Islam Terpadu Subulul Huda yang sebelumnya telah dimiliki oleh Yayasan Pendidikan dan Pondok Pesantren Subulul Huda. Hal ini sebagaimana yang disampaikan oleh kepala SMK BP Subulul Huda sebagai berikut, “.....Untuk pasar kita sementara ini memang dari SMP (SMP IT Subulul Huda) dan dari anaknya para alumni, karena sekolah yang lahir di tengah jalan yang notabene belum ada apa-apa, kan kita memulai betul-betul dari nol ... bahkan mungkin minus di bawah nol karena kita pinjam gedungnya...."’3

Berdasarkan deskripsi data di atas, kepala SMK Subulul Huda, berusaha untuk mengidentifikasi siapa saja pihak-pihak terkait yang dapat memengaruhi atau terpengaruh atas keputusannya, yaitu: calon peserta didik dan pemerintah provinsi Jawa Timur. Edward Sallis menjelaskan bahwa pelanggan pendidikan adalah 1) pelajar atau peserta didik (pelanggan eksternal utama), 2) orang tua/sponsor (pelanggan eksternal kedua), 3) pemerintah/masyarakat/bursa kerja (pelanggan eksternal ketiga), dan 4) guru/staf (pelanggan internal) ${ }^{14}$. Pertimbangan Kepala SMK BP Subulul Huda dalam memutuskan jurusan yang akan dibuka adalah dengan mempertimbangkan siapa calon konsumen pendidikan yang akan ditarget dan apa kebutuhan konsumen tersebut. Dalam hal ini kepala SMK BP Subulul Huda telah mengidentifikasi yaitu calon peserta didik (pelanggan eksternal utama), dan pemerintah provinsi Jawa Timur (pelanggan eksternal ketiga). Dari kedua konsumen tersebut ternyata memiliki kebutuhan yang berbeda. Pihak pemerintah provinsi Jawa Timur mengharapkan jurusan yang dibuka adalah jurusan otomotif, pertanian atau teknik pengolahan hasil pertanian. Harapan tersebut tentunya disesuaikan dengan potensi yang dimiliki oleh daerah di mana sekolah didirikan sebagaimana yang diharapkan oleh Direktorat Pembinaan Sekolah Menengah Kejuruan, Direktorat Jenderal Pendidikan Dasar dan Menengah, Kementerian Pendidikan dan Kebudayaan Republik Indonesia ${ }^{15}$. Sedangkan kebutuhan calon peserta didik dalam pandangan kepala SMK Subulul Huda adalah jurusan yang sejalan dengan perkembangan zaman atau terkait dengan potensi pemanfaatan teknologi informasi (TI). Jurusan yang sejalan dengan perkembangan zaman dalam pandangan kepala SMK BP Subulul Huda adalah Perbankan Syariah (PBS) dan Rekayasa Perangkat Lunak (RPL).

Sebenarnya kedua konsumen pendidikan tersebut dapat dilayani kebutuhannya semua yaitu dengan membuka lima jurusan sekaligus sesuai yang diharapkan oleh kedua konsumen, namun ada beberapa alasan yang tidak memungkinkan alternatif tersebut dipilih. Pemilihan tersebut juga bukan tanpa alasan, karena pada awal pendirian SMK Subulul Huda, waktu yang tersedia sangat singkat dengan dimulainya tahun ajaran baru waktu itu sehingga untuk menjalankan program-program pemasaran dengan menarget pelanggan secara lebih luas sangat kecil sekali dilakukan di tahun pertama pendirian sekolah. Hal tersebut sebagaimana pengakuan Kepala Sekolah SMK BP Subulul Huda bahwa sekolah mendapatkan SK pendirian pada saat di pertengahan jalan, ketika sebagian pasar yang akan ditarget sudah menentukan pilihan melanjutkan sekolah ke sekolah lain, sedangkan sekolah belum memiliki daya tarik yang signifikan untuk menarik pasar karena belum punya gedung ataupun sarana dan prasarana lainnya. Mungkin, daya tarik satu-satunya adalah kepercayaan terhadap kredibilitas Pondok Pesantren Subulul Huda saja saat itu. Pasar realistis yang dapat ditarget saat itu adalah alumni SMP IT Subulul Huda yang jumlahnya tidak banyak karena sebagian alumni sudah terlebih

\footnotetext{
${ }^{12}$ Muchtim Humaidi, Wawancara, 2019.

${ }^{13}$ Humaidi.

${ }^{14}$ Edward Sallis, Total Quality Management In Education (Yogyakarta: IRCiSoD, 2008).

${ }^{15}$ Chrismi Widjajanti dkk., Panduan Sinkronisasi Bidang Keahlian Di SMK Dengan Prioritas Potensi Unggulan Wilayah Dan Tenaga Kerja (Direktorat Pembinaan Sekolah Menengah Kejuruan, Direktorat Jenderal Pendidikan Dasar dan Menengah, Kementerian Pendidikan dan Kebudayaan RI, 2017).
} 
dahulu memilih sekolah di tempat lain, sedangkan pada saat itu SMK BP Subulul Huda belum didirikan. Proses mengidentifikasi dan mengelompokkan pasar kemudian memilih pasar mana yang lebih realistis akan dilayani seperti ini disebut juga dengan proses segmentasi pasar dan targeting (membidik pasar) ${ }^{16}$. Targeting dilakukan karena dalam pemasaran mengajarkan bahwa tidak mungkin semua pasar dapat dipuaskan secara bersamaan dengan satu produk, jadi harus fokus memilih pasar untuk dipuaskan. Pemilihan segmen pasar yang akan dilayani (targeting) yang dilakukan oleh Kepala SMK BP Subulul Huda tersebut dapat dibenarkan karena segmen pasar yang dipilih dapat diakses (accessibility) dan program pemasaran dapat dilaksanakan pada segmen pasar tersebut, dan pemilihan segmen pasar tersebut didasari oleh berbagai pertimbangan kondisi, waktu, dan sumber daya yang dimiliki oleh SMK BP Subulul Huda saat itu. Targeting tersebut sejalan dengan persyaratan segmentasi yang efektif yaitu dapat diukur, jumlahnya cukup besar, dapat diakses, dapat dibedakan, dan dapat diambil tindakan (programprogram pemasaran dapat dijalankan untuk melayani segmen tersebut). ${ }^{17}$ Targeting tersebut juga sejalan dengan apa yang disampaikan oleh Hermawan Kartajaya, bahwa dalam membidik pasar (targeting) harus mempertimbangkan kemampuan organisasi untuk melayani segmen yang dipilih tersebut. ${ }^{18}$

Sebagaimana yang dijelaskan di atas, bahwa Kepala SMK BP Subulul Huda juga telah mengidentifikasi pasar yang lain yaitu Pemerintah Provinsi Jawa Timur. Memang segmen pasar ini menurut Edward Sallis bukan merupakan calon pelanggan utama (tetapi pelanggan eksternal ketiga), namun sangat penting untuk dipertimbangkan dan dilayani karena mereka adalah pembuat kebijakan yang memiliki kepentingan terhadap arah, hasil, dan kualitas pendidikan di Jawa Timur khususnya dan Indonesia pada umumnya. Jika segmen ini tidak dapat dipenuhi pada saat ini, setidaknya segmen ini bisa dipertimbangkan untuk dilayani di masa yang akan datang setelah sumber daya yang dimiliki, waktu, dan kondisi sudah memungkinkan. Itulah uniknya pemasaran jasa pendidikan.

Dalam sudut pandang yang lain, penentuan targeting dengan memilih segmen alumni SMP IT Subulul Huda merupakan strategi integrasi ke depan dengan maksud untuk meraih kendali atas jalur distribusi (dengan mendirikan dan memiliki sendiri jalur distribusi). ${ }^{19}$ Dalam hal ini pihak Yayasan Pondok Pesantren (ponpes) Subulul Huda berharap dapat menampung alumni SMP IT Subulul Huda untuk melanjutkan pendidikan ke jenjang yang lebih tinggi di lingkungan ponpes Subulul Huda.

Setelah melakukan segmentasi dan targeting, yang dilakukan oleh SMK BP Subulul Huda adalah menentukan positioning, yaitu suatu upaya merancang tawaran dan citra produk agar menempati posisi yang khas di benak konsumen (berbeda dibandingkan dengan pesaing $)^{20}$. Sebagaimana hasil wawancara, positioning yang dipilih oleh kepala SMK BP Subulul Huda adalah ingin membangun sekolah SMK Berbasis Pesantren atau lebih lengkapnya adalah sesuai visi SMK BP Subulul Huda yaitu ingin mengupayakan "Terwujudnya layanan pendidikan unggul berbasis pesantren yang mampu mencetak lulusan yang terampil, inovatif, kreatif, dedikatif, kompetitif, dan berwawasan global berbasiskan ilmu dan adab". Sejak beroperasi, kepala SMK BP Subulul Huda berkomitmen ingin menjadikan sekolah tersebut berbasis pesantren yang mengintegrasikan kurikulum DIKNAS dengan nilai-nilai pondok (kepesantrenan). Hal itu didukung dengan penetapan visi yang telah dijelaskan di atas. Selain itu, sebagaimana pengakuan Kepala SMK BP Subulul Huda bahwa Kepala SMK BP Subulul Huda telah menolak beberapa calon peserta didik yang ingin sekolah di SMK BP Subulul Huda namun hanya ingin sekolah saja tanpa mau mondok (tidak mau tinggal di pondok pesantren), "Ada beberapa yang

\footnotetext{
${ }^{16}$ Philip Kotler dan Kevin Lane Keller, Manajemen Pemasaran Jilid 1, 12 ed. (Jakarta Barat: PT. Indeks, 2016).

${ }^{17}$ Philip Kotler, Manajemen Pemasaran Jilid 1 (Jakarta: PT. Prenhallindo, 1997).

${ }^{18}$ Hermawan Kartajaya dkk., Positioning, Diferensiasi,dan Brand (PT Gramedia Pustaka Utama, 2004).

${ }^{19}$ Kotler dan Keller, Manajemen Pemasaran Jilid 1.

${ }^{20}$ Kotler dan Keller.
} 
mau daftar kesini tapi tidak mau mondok.... kalau misal kita terima berarti mundur... kemunduran..... kita ini marketing-nya jangka panjang...... " ${ }_{21}$

Komitmen Kepala SMK BP Subulul Huda tersebut sangat penting untuk menguatkan positioning yang telah ditetapkan yaitu membangun persepsi masyarakat bahwa SMK Subulul Huda adalah SMK yang Berbasis Pesantren (wajib mondok). Ini merupakan salah satu upaya untuk melakukan diferensiasi SMK BP Subulul Huda terhadap SMK lain yang ada di sekitar lingkungan ponpes Subulul Huda.

Bentuk diferensiasi yang lainnya adalah terkait profil lulusan yang diharapkan oleh kepala SMK BP Subulul Huda adalah beliau menegaskan bahwa lulusan SMK BP Subulul Huda harus memiliki beberapa keunggulan yang merupakan penggabungan dari profil lulusan SMA, MA/MAN dan SMK secara umum. Sebagaimana yang disampaikan kepala SMK BP Subulul Huda, "Lulusan SMK BP Subulul Huda harus memiliki keunggulan pengetahuan seperti lulusan SMA pada umumnya, harus memiliki ketrampilan seperti ketrampilan lulusan SMK pada umumnya, dan harus memiliki akhlak yang lebih baik dari lulusan MA/MAN pada umumnya."22

Sebagaimana yang dikatakan oleh bapak pemasaran Indonesia yaitu Hermawan Kartajaya, bahwa positioning adalah janji yang diberikan produk, merek, dan perusahaan/ lembaga/organisasi. Untuk memenuhi janji tersebut, organisasi harus membangun diferensiasi yang kokoh melalui tiga aspek yaitu dari sisi kontennya atau apa yang ditawarkan (what to offer), dari sisi konteksnya atau bagaimana cara menawarkannya (how to offer), dan dari sisi infrastrukturnya atau faktor pemungkinnya (enabler) baik dalam bentuk SDM, teknologi, dan fasilitas. ${ }^{23}$ Untuk membangun diferensiasi tersebut dari sisi konten, SMK BP Subulul Huda menawarkan dua jurusan bidang keahlian yaitu SMK jurusan RPL dan PBS; dari sisi konteks, pendidikan dilakukan berbasiskan pesantren (peserta didik wajib mondok); dari sisi infrastruktur, SMK BP Subulul Huda didirikan di dalam ponpes dan sudah memiliki SDM yang memadai meskipun masih terbatas jumlahnya.

Keputusan-keputusan terkait proses segmentasi pasar, targeting, dan positioning tersebut merupakan keputusan-keputusan strategis yang menjadi dasar atau harus di-back up dengan strategi-strategi lainnya (Hermawan Kartajaya menyebut strategi-strategi lainnya dengan taktik (tactic) dan nilai (value)). ${ }^{24}$ Kegagalan dalam melakukan proses segmentasi pasar, targeting, dan positioning dapat berdampak pada kegagalan suatu organisasi.

Perencanaan pemasaran lainnya adalah terkait perencanaan target jumlah peserta didik yang ingin dicapai oleh SMK BP Subulul Huda. Sebagaimana hasil wawancara, pada awal berdiri target awal atau target jangka pendek adalah 15 peserta didik saja dalam rangka untuk memenuhi syarat penerbitan SK pendirian sekolah. Pada tahun pertama, SMK BP Subulul Huda dapat melampaui harapan yaitu mendapatkan peserta didik sebanyak 25 peserta didik. Hal ini sebagaimana yang disampaikan oleh Kepala Sekolah SMK BP Subulul Huda, "Dulu itu target minimal dari pihak sana (pemerintah) 15 tapi kita dapat 25 (pesdik)." ${ }^{25}$

Seiring waktu SMK BP Subulul Huda menentukan target tiap tahun dapat menerima peserta didik sebanyak 50 peserta didik. Target SMK BP Subulul Huda untuk jangka panjang adalah dapat memiliki peserta didik minimal 250 peserta didik. Menurut kepala Sekolah SMK BP Subulul Huda, jika SMK BP Subulul Huda sudah mampu mendapatkan siswa sebanyak minimal 250 siswa, sekolah sudah bisa mandiri, hal itu sebagaimana pengalaman kepala sekolah SMK BP Subulul Huda saat mengelola SMP IT pada waktu dulu. ${ }^{26}$

Dari perencanaan tersebut dapat disimpulkan bahwa SMK BP Subulul Huda memiliki perencanaan pemasaran jangka pendek, jangka menengah, dan jangka panjang terkait target

\footnotetext{
${ }^{21}$ Humaidi, Wawancara.

${ }^{22}$ Humaidi.

${ }^{23}$ Kartajaya dkk., Positioning, Diferensiasi,dan Brand.

${ }^{24}$ Kartajaya dkk.

${ }^{25}$ Humaidi, Wawancara.

${ }^{26}$ Humaidi.
} 
jumlah peserta didik. Target jangka pendek adalah mendapatkan 15 peserta didik sebagai syarat penerbitan SK pendirian sekolah, jangka menengah adalah mendapatkan 50 peserta didik tiap tahun agar tetap eksis, dan target jangka panjang adalah 250 peserta didik agar sekolah SMK BP Subulul Huda dapat mandiri.

\section{Strategi Implementasi Pemasaran Jasa Pendidikan di SMK BP Subulul Huda}

Sebagaimana dijelaskan di atas bahwa segmentasi, targeting, dan positioning yang telah ditetapkan akan menjadi dasar untuk menjalankan strategi lainnya. Hermawan Kartajaya menyebut strategi-strategi lainnya tersebut sebagai taktik (tactic) dan nilai (value). Strategi terdiri dari segmentation, targeting, dan positioning; taktik terdiri dari differentiation, marketing mix (product, price, place, promotion), dan selling; serta value terdiri dari brand, service, dan process $^{27}$. Taktik adalah pelaksanaan strategi. ${ }^{28}$ Jadi beberapa aspek tersebut (taktik dan nilai) diupayakan dalam rangka untuk mengimplementasikan strategi pemasaran jasa pendidikan di SMK BP Subulul Huda yang telah direncanakan sebagaimana yang dijelaskan di atas.

Sedangkan McCarthy mengenalkan konsep bauran pemasaran (marketing mix) dengan istilah ${ }_{4} \mathrm{P}$ (product, price, place, dan promotion). Untuk produk jasa, James dan Phillips menambah ${ }_{4} \mathrm{P}$ tersebut dengan ${ }_{3} \mathrm{P}$ (people, physical evidence, dan process) sehingga menjadi ${ }_{7} \mathrm{P} .{ }^{29}$ Untuk mengetahui bagaimana implementasi pemasaran jasa pendidikan di SMK BP Subulul Huda, maka dapat dideskripsikan strategi-strategi lain (bauran pemasaran) yang telah dilakukan oleh Kepala SMK BP Subulul Huda.

\section{a. Produk (Product)}

Produk yang ditawarkan oleh SMK BP Subulul Huda adalah jasa pendidikan dalam bentuk SMK Berbasis Pesantren dengan jurusan atau bidang keahlian Perbankan Syariah (PBS) dan Rekayasa Perangkat Lunak (RPL). Penentuan produk tersebut tentu saja melalui berbagai pertimbangan. Sebagaimana yang disampaikan oleh kepala SMK BP Subulul Huda bahwa sebenarnya yang diharapkan oleh pihak provinsi adalah jurusan otomotif, pertanian atau teknik pengolahan hasil pertanian. Sesuai pengakuan bapak Muchtim Humaidi selaku Kepala SMK BP Subulul Huda, bahwa beliau tidak berani memilih jurusan tersebut karena dalam pandangannya yang akan mendaftar itu kebanyakan perempuan, disamping itu jurusan otomotif itu secara sarana dan prasarana juga mahal (memerlukan biaya yang lebih banyak). Bapak Muchtim Humaidi akhirnya memutuskan untuk membuka jurusan Perbankan Syariah, karena bidang ekonomi syariah menurutnya saat itu memiliki prospek yang bagus hingga sepuluh sampai dengan lima belas tahun ke depan, selain itu input siswa pada saat itu diperkirakan kebanyakan perempuan karena memang lulusan siswa SMP (SMP IT Subulul Huda) banyak yang perempuan. Selain itu SDM (guru) dan jaringan yang dimiliki dari kalangan intelektual yang basic-nya ekonomi syariah itu banyak. Selain itu, bapak Muchtim Humaidi beranggapan bahwa SMK Subulul Huda berada di lingkungan pesantren jadi kalau membuka jurusan ekonomi syariah itu sangat tepat karena berbasis pesantren. Jurusan yang dibuka lainnya adalah RPL (Rekayasa Perangkat Lunak). Menurut Muchtim Humaidi, saat ini kebanyakan anak lebih senang dengan komputer daripada bertani. Beliau juga memprediksi bahwa di masa yang akan datang orang yang pintar dalam bidang komputer dan hitung-hitungan (matematika), ketika ingin melanjutkan studi ke mana saja insyaAllah tetap akan lebih mudah dan terbantu. Masih menurut beliau, Yayasan Subulul Huda mendirikan dan menentukan jurusan itu memang berdasarkan (kebutuhan) pasar..$^{30}$

\footnotetext{
${ }^{27}$ Hermawan Kartajaya dkk., Rethinking Marketing Sustainable Market-ing Enterprise di Asia, Bahasa Indonesia (Jakarta: PT. Indeks, 2005).

28 "Kamus Besar Bahasa Indonesia (KBBI) Versi Online," https://kbbi.web.id/taktik, t.t., diakses 2 Juli 2019.

29 Wijaya, Pemasaran Jasa Pendidikan.

${ }^{30}$ Humaidi, Wawancara..
} 
Di sisi yang lain, dalam rangka memutuskan produk (jurusan), sebelumnya pihak SMK BP subulul Huda juga melakukan survei dan observasi kepada peserta didik SMP IT Subulul Huda (prospek). Berikut ini adalah pengakuan kepala SMK BP Subulul Huda:

Sempat mengumpulkan anak-anak yang dari SMP, jadi kita itu berdirinya di tengah jalan ketika anak-anak SMP sudah menentukan pilihan ke sekolah jenjang lanjutan, kita baru dapat SK pendirian. ........ saya tanya ke anak-anak itu, yang jelas anak-anak itu suka komputer, yang kedua ya karena cewek, apa ya yang pas ? Dan saya mengarahkan peluang ekonomi syariah di Madiun ini. (Jurusan) Perbankan Syariah sekabupaten dan sekota Madiun hanya ada dua di sini dan di Geger, artinya kan pasar atau potensi untuk bisa berkembang masih besar karena tidak ada persaingan. ${ }^{31}$

Sebagaimana yang dijelaskan di atas proses segmentasi pasar, targeting, dan positioning akan memengaruhi strategi-strategi selanjutnya. Sebagaimana dijelaskan di atas, bahwa SMK BP Subulul Huda telah melakukan targeting dan Kepala SMK BP Subulul Huda memilih pasar untuk sementara (saat itu) adalah alumni SMP IT Subulul Huda khususnya yang perempuan. Berhubung sudah jelas siapa pasar yang dibidik, langkah selanjutnya adalah mengidentifikasi kebutuhan dan keinginan pasar sasaran. Untuk memenuhi usaha tersebut, Kepala SMK BP Subulul Huda telah mengumpulkan pasar sasaran (peserta didik SMP IT Subulul Huda). Selanjutnya pasar sasaran disurvei apa kebutuhan dan keinginan mereka.

Selain melakukan survei, Kepala SMK BP Subulul Huda juga memiliki pertimbangan jurusan apa yang sekiranya cocok untuk perempuan dan ketrampilan apa yang akan didapatkan oleh lulusan agar nantinya dapat digunakan setidaknya untuk 1o s.d 15 tahun ke depan. Pada akhirnya telah diputuskan produk (jurusan) yang dibuka adalah jurusan Perbankan Syariah (PBS) dan Rekayasa Perangkat Lunak (RPL). Kedua jurusan tersebut dianggap dapat mempresentasikan sebagai produk yang dapat memenuhi kebutuhan dan keinginan pasar sasaran yang dibidik.

Kepala SMK BP Subulul Huda juga menyampaikan bahwa pemilihan produk (jurusan) PBS dan RPL tersebut tidak hanya berdasarkan pertimbangan kebutuhan dan keinginan pasar sasaran saja, namun juga telah mempertimbangkan analisis lingkungan, yaitu: kemampuan dan ketersediaan sumber daya yang dimiliki yayasan (SDM, kemampuan pembiayaan, dan gedung), jaringan yang dimiliki yayasan (jaringan dari kalangan intelektual yang basic-nya ekonomi syariah), dan juga kondisi persaingan (di wilayah Madiun Selatan tidak banyak SMK yang membuka jurusan PBS dan RPL) ${ }^{32}$. Menurut Kepala SMK BP Subulul Huda, dua jurusan tersebut biayanya (untuk sarana dan prasarana) lebih murah daripada jurusan otomotif dan juga lebih menarik daripada teknik pengolahan hasil pertanian karena adanya tuntutan zaman di mana anak zaman sekarang lebih suka mengoperasikan komputer. Pertimbangan ini sejalan dengan salah satu persyaratan segmentasi yang efektif yaitu dapat dilaksanakan, artinya program yang efektif dapat dirancang untuk menarik dan melayani segmen tersebut. ${ }^{33}$ Sebagaimana diketahui program yang efektif dapat dilaksanakan jika didukung dengan adanya sumber daya yang memadai. ${ }^{34}$

Sebelum menentukan jurusan, SMK BP Subulul Huda juga menganalisis kondisi pesaing, sebagaimana yang disampaikan oleh Kepala Sekolah SMK BP Subulul Huda berikut ini : "SMK yang paling dekat ini SMKN Kebonsari dan SMKN Geger. Tapi untuk jurusannya antara yang di sini (SMK BP Subulul Huda) dengan di Kebonsari tidak ada yang sama. ......di Kebonsari yang ada TKJ (Teknik Komputer dan Jaringan), kalau yang di Geger, yang sama satu PBS......Tapi tetap kita punya kekhasan-lah yaitu mondok......"35

\footnotetext{
${ }^{31}$ Humaidi.

${ }^{32}$ Humaidi.

33 Kotler, Manajemen Pemasaran Jilid 1.

${ }^{34}$ Kartajaya dkk., Positioning, Diferensiasi,dan Brand.

${ }^{35}$ Humaidi, Wawancara.
} 
Strategi memilih membuka jurusan RPL dan PBS yang berbeda atau tidak banyak dibuka oleh SMK lain disebut juga dengan blue ocean strategy. Blue ocean strategy adalah menciptakan ruang pasar yang belum ada pesaingnya dengan menciptakan suatu nilai dan keunikan yang tidak sembarang unik, namun juga merupakan pangsa pasar menguntungkan ${ }^{36}$.

Sebagaimana yang disampaikan oleh Kepala SMK BP Subulul Huda, bahwa SMK BP Subulul Huda adalah salah satu lembaga pendidikan berbasis pesantren di wilayah Madiun yang berupaya untuk mengintegrasikan Kurikulum Pendidikan Nasional dengan nilai-nilai Kepesantrenan. Untuk mendukung pelaksanaannya, secara comperhensive control dilakukan dalam pengawasan ustad dan pengasuh. ${ }^{37}$ Berdasarkan pernyataan Kepala SMK BP Subulul Huda tersebut, SMK BP Subulul Huda juga menjalankan strategi diferensiasi terhadap SMK lain yaitu SMK berbasis pesantren (peserta didik wajib mondok) yang tidak dilakukan oleh sebagian besar SMK di sekitar SMK BP Subulul Huda. Strategi diferensiasi yang dipilih tersebut dapat dikatakan sejalan dengan strategi fokus diferensiasi yang merupakan bagian dari strategi keunggulan bersaing Michael Porter. ${ }^{3}$ Strategi fokus diferensiasi ini sangat tepat dipilih jika kondisi sumber daya yang dimiliki oleh organisasi sangat terbatas.

Untuk menaikkan nilai produk (kualitas jasa), SMK BP Subulul Huda berupaya menawarkan program-program unggulan. Berikut ini adalah program-program unggulan SMK BP Subulul Huda:39

1. Program Kelas Khusus Wirausaha Mandiri

2. Program Kelas Samsung (Samsung Tech Institute)

3. Program Kelas Reparasi Sepeda Motor

4. Integrasi Kurikulum Pendidikan Nasional dengan Nilai-nilai Program Kepesantrenan

5. Berbasis Pesantren dengan Totaly Control 24 jam di bawah pengawasan ustad \& pengasuh.

6. Program Praktik Kerja Industri (Prakerin)

Dalam rangka meningkatkan nilai produk (kualitas jasa), SMK BP Subulul Huda juga menjalin kerja sama dengan berbagai pihak, baik pihak pemerintah maupun pihak swasta (dunia usaha dan dunia industri). Beberapa pihak swasta yang telah bekerja sama dengan SMK BP Subulul Huda di antaranya: Samsung Indonesia dan BMD Syariah Dolopo.

Jadi meskipun jurusan yang dibuka adalah PBS dan RPL, namun dalam praktiknya banyak program-program unggulan tambahan yang ditawarkan kepada peserta didik. Hal ini menandakan bahwa SMK BP Subulul Huda sangat memperhatikan kualitas lulusannya. Diferensiasi-diferensiasi di atas (jurusan yang berbeda dengan sekolah lainnya, sekolah berbasis pesantren, dan program-program unggulan tambahan) merupakan upaya untuk menguatkan positioning yang telah ditetapkan. Positioning yang didukung oleh diferensiasi yang kokoh akan menghasilkan brand integrity yang kuat. Brand integrity yang kuat pada gilirannya akan menghasilkan brand image yang kuat. Brand image yang kuat pada akhirnya akan memperkuat positioning. ${ }^{40}$

\section{b. Harga (Price)}

Penentuan harga merupakan ciri khas dari pemasaran dalam rangka untuk melakukan pertukaran. Berikut ini adalah harga (SPP) yang ditentukan oleh SMK BP Subulul Huda dalam tiga tahun ini:

\footnotetext{
36 "Strategi Samudera Biru," diakses 5 Oktober 2019, https://id.wikipedia.org/wiki/Strategi_samudera_biru.

37 "Sambutan Kepala Sekolah," Web Sekolah, diakses 1 Oktober 2019, http://smkbpsubululhuda.mysch.id.

${ }^{38}$ Meirani Harsasi, Pengembangan Produk (Tangerang Selatan: Universitas Terbuka, 2014).

39 "Pendaftaran," Web Sekolah, diakses 1 Oktober 2019,

http://smkbpsubululhuda.mysch.id/pendaftaran/.

${ }^{40}$ Kartajaya dkk., Rethinking Marketing Sustainable Market-ing Enterprise di Asia.
} 
Tabel 2. Harga (SPP) SMK BP Subulul Huda

\begin{tabular}{|l|l|}
\hline \multicolumn{1}{|c|}{ TAHUN MASUK } & \multicolumn{1}{c|}{ HARGA } \\
\hline $2017 / 2018$ & Rp o; (Gratis) \\
\hline $2018 / 2019$ & Rp 68.00o; \\
\hline $2019 / 2020$ & Rp 70.000; \\
\hline
\end{tabular}

Daftar harga atau SPP tersebut didapatkan dari hasil wawancara dengan Kepala Sekolah SMK BP Subulul Huda, berikut ini:

Dulu gratis, untuk yang pertama gratis, semua dikasih, SPP tidak membayar, seragam dikasih, jas almamater dikasih, untuk (tahun) yang kedua bayar, dua tahun kedua bayar 68 (Rp 68.00o) SPP-nya, kalau di Negeri itu 180 (Rp 180.00o) itu Negeri ... tahun ketiga naik 2.00o, (menjadi) 7o (Rp 70.00o), tapi ini kalau BOS sudah turun mau digratiskan karena aturan dari pemerintah provinsi kan ada program tistas (gratis berkualitas) tapi sepertinya program ini lebih mengedepankan sekolah-sekolah yang negeri, jadi negeri itu sudah lama turunnya, swasta dereng (belum).... ${ }^{41}$

Jika produk yang sesuai dengan kebutuhan dan keinginan pasar telah ada, maka langkah selanjutnya adalah penentuan harga. Berdasar tabel 2 di atas bahwa pada tahun pertama SPP digratiskan. Kebijakan SPP gratis pada tahun pertama ini kalau ditinjau berdasarkan tujuan penetapan harga maka ada beberapa tujuan yaitu untuk maksimasi pangsa pasar, mencapai tingkat penjualan tertentu (target jumlah penerimaan peserta didik), dan menjadi strategi bersaing dengan SMK lainnya..$^{2}$ Kebijakan SPP gratis pada tahun pertama ini juga menjadi pembeda pemasaran di bidang organisasi nirlaba yang jarang dijumpai pada organisasi laba.

Menurut Kepala SMK BP Subulul Huda, SPP pada tahun kedua dan ketiga tidak lagi gratis, peserta didik dikenakan SPP Rp 68.0oo; untuk tahun kedua dan Rp 70.ooo; untuk tahun ketiga. Harga (SPP) ini bisa dikatakan lebih murah dibandingkan dengan SPP SMK Negeri yang belum menerima BOS (Bantuan Operasional Sekolah) yaitu sebesar Rp 180.ooo. Penentuan harga yang relatif murah ini bisa dikatakan sebagai strategi rapid-penetration strategy yaitu produk ditawarkan dengan harga rendah dan kegiatan promosi yang tinggi. Strategi rapidpenetration strategy merupakan strategi yang umum digunakan sebagai strategi peluncuran produk baru yang masih berada pada tahap perkenalan dalam siklus hidup produk. ${ }^{43}$

\section{c. Saluran Pemasaran (Place)}

Lokasi SMK BP Subulul Huda sangat strategis karena mudah dijangkau kendaraan, baik kendaraan roda 2 maupun roda 4. Lebih tepatnya, SMK BP Subulul Huda berlokasi di Jl. Anggur RT o8 RW 02 Kembangsawit, Desa Rejosari, Kecamatan Kebonsari, Kabupaten Madiun, Provinsi Jawa Timur. Lokasi SMK BP Subulul Huda berdekatan dengan kecamatan Takeran (sebelah barat), kecamatan Dolopo (sebelah selatan dan timur), dan kecamatan Geger (sebelah utara dan timur).

SMK BP Subulul Huda yang lokasinya menjadi satu area dengan pondok pesantren Subulul Huda dapat memberikan daya tarik dan sekaligus memperkuat positioning yang telah ditetapkan. Salah satu kekurangan terkait lokasi ini adalah tidak adanya kendaraan umum yang secara rutin lewat di depan atau di sekitar SMK BP Subulul Huda. Meskipun demikian kekurangan tersebut dapat teratasi dengan mudahnya mendapatkan jasa ojek online di sekitar wilayah Kebonsari.

Informasi di atas adalah terkait lokasi SMK BP Subulul Huda. Selain itu, informasi yang perlu diketahui terkait saluran pemasaran (place) SMK BP Subulul Huda ini adalah kelas sebagai

\footnotetext{
${ }^{41}$ Humaidi, Wawancara.

${ }^{42}$ RW Suparyanto dan Rosad, Manajemen Pemasaran Dilengkapi 45 Judul Penelitian dan Kasus sehari-

hari di Indonesia (Bogor: In Media, 2015).

43 Kotler, Manajemen Pemasaran Jilid 1.
} 
tempat penyampaian jasa pendidikan. Pada awalnya SMK BP Subulul Huda tidak memiliki kelas sama sekali, sehingga proses belajar mengajar masih pinjam. Hal tersebut sesuai pengakuan Kepala SMK BP Subulul Huda, “...sekolah yang lahir di tengah jalan yang notabene belum ada apa-apa, kan kita memulai betul-betul dari nol ... bahkan mungkin minus di bawah nol karena kita pinjam gedungnya.." 44

Pada tahun pertama, SMK BP Subulul Huda belum memiliki ruang kelas sendiri sehingga proses belajar mengajar harus pinjam. Kepala SMK BP Subulul Huda tidak tinggal diam, beliau berusaha untuk membangun ruang kelas, namun karena ada keterbatasan biaya akhirnya berusaha mengajukan proposal bantuan kepada pemerintah. Pemerintah termasuk pelanggan jasa pendidikan. Menurut Edwards Salis (2008), pemerintah termasuk pelanggan eksternal ketiga. ${ }^{45}$ Tidak bisa dipungkiri bahwa pemerintah memiliki kepentingan terhadap arah, kualitas, dan keberhasilan pendidikan di Indonesia, sehingga melibatkan pemerintah ke dalam pembangunan ruang kelas di SMK BP Subulul Huda merupakan pilihan yang tepat. Menurut pengakuan Kepala SMK BP Subulul Huda, pengajuan proposal kepada pemerintah berhasil dan mendapatkan bantuan dua ruang kelas. Untuk menggenapi, pihak SMK BP Subulul Huda membangun sendiri empat kelas, sehingga tahun 2019 SMK BP Subulul Huda sudah memiliki enam kelas. Selain mendapatkan bantuan dua ruang kelas, SMK BP Subulul Huda juga mendapatkan bantuan satu ruang RPS (Ruang Praktik Siswa). ${ }^{46}$ Percepatan pemenuhan ruang kelas dan ruang praktik siswa tersebut merupakan keputusan yang tepat. Dalam pemasaran, place (saluran distribusi) jasa pendidikan dalam wujud kelas ini memang menjadi suatu keharusan untuk dipenuhi karena penyampaian jasa pendidikan dilakukan dalam kelas tersebut. Sebagaimana diketahui salah satu karakteristik jasa adalah inseparability (tidak dapat dipisahkan) yaitu jasa dihasilkan (diproduksi) dan dikonsumsi secara bersamaan (dalam kelas tersebut). ${ }^{47}$ Usaha Kepala SMK BP Subulul Huda tersebut dalam pemasaran dapat dikatakan sebagai megamarketing. Menurut Philip Kotler megamarketing adalah memanfaatkan lobi-lobi politik secara legal kepada pihak pemerintah. ${ }^{48}$ Dalam hal ini pemerintah sebagai pembuat kebijakan sekaligus sebagai pelanggan eksternal ketiga yang tentu saja berkepentingan terhadap suksesnya pendidikan di Indonesia, khususnya di wilayah Jawa Timur. Sebagaimana dijelaskan di atas bahwa pemerintah sedang menggalakkan program revitalisasi sekolah menengah kejuruan dalam rangka peningkatan kualitas dan daya saing sumber daya manusia Indonesia sejak tahun 2016, sehingga upaya SMK Subulul Huda tersebut sudah selayaknya mendapat dukungan dari pemerintah karena juga menguntungkan pemerintah. Situasi seperti ini juga merupakan salah satu hal yang membedakan antara organisasi nirlaba (dalam bidang pendidikan) dengan organisasi laba pada umumnya.

\section{d. Promosi (Promotion)}

Promosi yang dilakukan SMK BP Subulul Huda cukup bervariasi. Pada saat peresmian, SMK BP Subulul Huda mendatangkan Bapak Bupati Madiun saat itu yaitu Bapak H. Muhtarom, S.Sos. Kehadiran Bapak H. Muhtarom, S.Sos pada saat peresmian memiliki banyak manfaat. Ditinjau dari sudut pemasaran, manfaat pertama adalah sebagai salah satu upaya untuk menjaga hubungan sekolah dan pemerintah. Menjalin hubungan ini sangat penting karena pemerintah merupakan pelanggan eksternal ketiga yang memiliki kepentingan terhadap arah, kualitas, dan keberhasilan pendidikan di Indonesia. Manfaat kedua adalah kegiatan tersebut merupakan salah satu upaya untuk mengenalkan keberadaan SMK BP Subulul Huda kepada masyarakat. Kedatangan seorang Bupati diharapkan akan mengundang perhatian masyarakat, sehingga

\footnotetext{
${ }^{44}$ Humaidi, Wawancara.

${ }^{45}$ Sallis, Total Quality Management In Education.

${ }^{46}$ Humaidi, Wawancara.

${ }^{47}$ Ririn Tri Ratnasari dan Mastuti Aksa, Teori dan Kasus Manajemen Pemasaran Jasa (Ghalia Indonesia, 2011).

${ }^{48}$ Kotler dan Keller, Manajemen Pemasaran Jilid 1.
} 
diharapkan masyarakat akan segera mengetahui atau menyadari eksistensi SMK BP Subulul Huda (awareness). Manfaat ketiga adalah untuk membangun kepercayaan kepada masyarakat. Bapak Bupati hadir di acara peresmian, berarti lembaga (SMK BP Subulul Huda) tidak bermasalah atau mendapat legalitas dari pemerintah sehingga diharapkan kepercayaan masyarakat meningkat. Kegiatan semacam ini merupakan tugas dan tanggung jawab pemasaran khususnya bagian hubungan masyarakat pemasaran. ${ }^{49}$ Apa yang dilakukan oleh pihak SMK BP Subulul Huda tersebut sangat tepat. Aktivitas pemasaran yang tepat untuk mempromosikan sebuah produk yang masih baru adalah membangun kesadaran merek (awareness) kepada segmen pasar yang ditarget. Sebagaimana diketahui Kotler dan Kartajaya mengenalkan jalur pelanggan di era marketing 4.0 yaitu aware (menyadari), appeal (tertarik), ask (bertanya), act (bertindak/membeli), dan advocate (menganjurkan)..$^{5^{\circ}}$ Berdasarkan jalur pelanggan tersebut menunjukkan bahwa aktivitas promosi kali pertama yang harus dilakukan terhadap produk baru adalah membangun kesadaran merek (awareness) kepada pasar yang ditarget. Upaya SMK BP Subulul Huda mendatangkan Bapak Bupati kala itu adalah salah satu pilihan yang tepat untuk membangun kesadaran merek kepada pasar yang ditarget.

Selain itu, promosi yang dilakukan SMK BP Subulul Huda adalah dalam bentuk periklanan, seperti membuat dan menyebarkan brosur. Tidak hanya itu, promosi lainnya dilakukan dengan berkunjung ke sekolah-sekolah SMP sederajat (personal selling) dan kegiatankegiatan lain semacam lomba-lomba. Aktivitas promosi tersebut seperti yang disampaikan kepala SMK BP Subulul Huda berikut ini:

....pernah (mengunjungi sekolah SMP) di Mejayan, di Saradan, di Kare,.... di sekitar sini ada juga, di MTSN Kembang Sawit, MTsN Rejosari, tapi kurang efektif, hasilnya dengan usaha yang sudah kita lakukan karena masyarakat atau anak sekarang itu lebih suka melihat gebyar fisiknya, ya satu, dua, tigalah yang tertarik ...... pernah kita membuat event juga, lomba, lomba pidato bahasa arab-bahasa inggris, terus lomba desain grafis dari antar sekolah SMP-MTs ... ya untuk mengenalkan mereka kalau di sini ada SMK. ${ }^{51}$

Berdasarkan pengakuan kepala SMK BP Subulul Huda tersebut tujuan promosi yang dilakukan, baik dalam bentuk personal selling maupun mengadakan lomba-lomba adalah masih dalam rangka untuk membangun kesadaran merek (awareness).

Dalam rangka untuk mendukung aktivitas promosi, SMK BP Subulul Huda juga memiliki akun facebook, Instagram (IG), dan Youtube yang dikelola oleh seorang ustad serta sebagai kontributor kontennya adalah peserta didik SMK BP Subulul Huda. Hal tersebut sebagaimana yang disampaikan oleh kepala SMK BP Subulul Huda sebagai berikut, “.....bagian adminnya ustad, terus untuk kontributornya anak-anak juga, jadi video-video yang di-upload itu kebanyakan ya hasil karya anak-anak, karena ada kegiatan ekstra bikin film, jadi yang layak tampil kita upload.." 52

Tidak hanya itu saja, seperti yang disampaikan Ustad Muchtim Humaidi, bahwa kegiatan promosi yang dilakukan SMK BP Subulul Huda tidak hanya menggunakan IG, Youtube, dan facebook saja, namun juga melalui forum wali santri, forum alumni, show-up ke luar, penjualan kalender ke wali santri, website sekolah, brosur, mengadakan lomba-lomba, dan melakukan personal selling ke sekolah-sekolah SMP yang sederajat di wilayah Madiun. Hal tersebut sebagaimana yang disampaikan oleh kepala SMK BP Subulul Huda sebagai berikut:

Sosmed niku mesti nggih (media sosial itu pasti ya), ada IG, ada facebook, terus kemudian kita juga ada forum wali santri, forum alumni sehingga setiap kali ada event

\footnotetext{
${ }^{49}$ Philip Kotler dan Kevin Lane Keller, Manajemen Pemasaran Jilid 2, 12 ed. (Jakarta Barat: PT. Indeks, 2007).

${ }^{50}$ Philip Kotler, Hermawan Kartajaya, dan Iwan Setiawan, Marketing 4.o Bergerak Dari Tradisional ke Digital (Jakarta: PT. Gramedia Pustaka Utama, 2019), 59.

${ }^{51}$ Humaidi, Wawancara.

${ }^{52}$ Humaidi.
} 
ada moment yang kita bisa dokumenkan kita share, kita ada kalender yang setiap tahun kita jual ke wali santri, terus kita mencoba aktif di kegiatan luaran show-up untuk menunjukkan eksistensi, bahwasanya di Kembangsawit itu ada SMK, dan ikut kegiatankegiatan perlombaan, kegiatan-kegiatan ... seperti hari santri itu kita membuat bazar di lapangan Mejayan sana,.... kita juga menampilkan drama kolosal di lapangan (Mejayan), itu kan juga anak SMK semua, artinya kita mencoba aktif show-up keluar agar masyarakat umum itu tahu bahwasanya di pondok kita ini ada SMK, jadi kita aktif, di MKKS dan lain-lain kita aktif, kemudian kita juga membuat web, ada youtube dan memang guru kami itu ada yang ahli. Kita sangat sangat support, ya tujuannya untuk melaporkan sejauh mana perkembangan dan kegiatan apa saja yang sudah kita lakukan sehingga masyarakat yang selama ini memasukkan anaknya ke SMK itu semakin yakin dengan pilihannya...53

Ditinjau dari konten periklanan, selain memberikan informasi tentang SMK kepada masyarakat juga ada satu hal yang perlu diperhatikan yaitu konsistensi mengenalkan logo SMK yang disertai dengan frase kata "SMK BP Subulul Huda". Huruf "BP" selalu ditampilkan di berbagai konten periklanan SMK BP Subulul Huda. "BP” tersebut merupakan kependekan dari "Berbasis Pesantren". Jadi penggunaan huruf "BP" tersebut bukan tanpa alasan melainkan sebagai wujud konsistensi pihak sekolah untuk menjalankan positioning yang telah ditetapkan. Sebagaimana dijelaskan di atas, SMK BP Subulul Huda sejak awal ingin dikenal masyarakat sebagai SMK yang berbasis pesantren. Jadi periklanan harus sejalan dan menguatkan positioning yang telah ditentukan.

Selain bentuk promosi tersebut, SMK BP Subulul Huda juga pernah melakukan promosi penjualan (sales promotion) yaitu menggratiskan SPP untuk peserta didik pada tahun pertama dan memberikan diskon $15 \%$ untuk pendaftar gelombang pertama pada penerimaan peserta didik baru tahun ajaran 2019/2020. Promosi penjualan pada umumnya dilakukan dengan cara memberikan insentif dan digunakan untuk waktu jangka pendek dalam rangka meningkatkan penjualan (mendapatkan siswa sebanyak-banyaknya), namun cara ini tidak efektif untuk membangun preferensi merek jangka panjang. ${ }^{54}$

Upaya promosi dalam bentuk yang lain, yaitu SMK BP Subulul Huda berusaha untuk melibatkan masyarakat di sekitarnya dalam berbagai kegiatan yang diadakan oleh sekolah. Sebagaimana yang disampaikan oleh Kepala SMK BP Subulul Huda, bahwa SMK BP Subulul Huda bekerja sama dengan BLK (Balai Latihan Kerja) Jawa Timur mengadakan pelatihan reparasi motor untuk 16 siswa dan masyarakat selama 30 hari. Selain itu SMK BP Subulul Huda mengadakan SMK Santripreneurship Festival (semacam bazar) kemudian mengundang masyarakat sekitar SMK BP Subulul Huda. Selain itu juga mengadakan lomba-lomba yang melibatkan masyarakat sekitar. ${ }^{55}$ Kegiatan tersebut diharapkan dapat menumbuhkan dan menjaga hubungan baik antara pihak SMK BP Subulul Huda dengan masyarakat di sekitar sekolah (ponpes). Dengan upaya sering menjalin hubungan dan melibatkan masyarakat di sekitar, tentunya dapat meningkatkan citra organisasi (SMK BP Subulul Huda). Membangun, menjaga, dan meningkatkan citra organisasi dari waktu ke waktu merupakan hal yang sangat penting bagi pemasar.

\section{e. Sumber Daya Manusia (People)}

SMK BP Subulul Huda memiliki sumber daya manusia (tenaga pendidik dan kependidikan) lulusan S1 (19 orang) dan lulusan S2 (5 orang). Dalam pemasaran jasa, memiliki sumber daya manusia yang unggul merupakan suatu keharusan karena mereka yang akan berhubungan langsung dalam proses produksi/penyampaian jasa kepada konsumen (peserta

\footnotetext{
${ }^{53}$ Humaidi, Wawancara.

54 Philip Kotler, Manajemen Pemasaran Jilid 2 (Jakarta: PT. Prenhallindo, 1997).

55 Humaidi, Wawancara.
} 
didik). Agar SDM yang dimiliki berkualitas, SMK BP Subulul Huda selalu berusaha untuk meningkatkan kualitas SDM yang dimilikinya, sebagaimana yang disampaikan oleh Bapak Muchtim Humaidi:

Pendidik sering kita ikutkan workshop-workshop, terus ada pelatihan-pelatihan. Contoh pelatihan bahasa Inggris itu setiap Jumat khusus untuk guru itu ada. Kami ini meskipun sekolah di desa tapi saya ingin anak-anak kami itu nanti ke depannya memiliki wawasan yang global, dan itu harus didukung dengan penguasaan skill bahasa, anak itu setiap hari ada delevering vocab, dikasih vocab itu. Nah tidak mungkin kemudian kami hanya mengajari anak, harus didukung dengan SDM guru yang juga minimal bolehlah ngomong meskipun sedikit, jadi SDM dari segi bahasa, terus ada setiap hari Selasa di minggu terakhir itu apa istilahnya ? pembinaan guru itu ada, agar supaya kita ini satu langkah, satu ritme, kemudian punya ruh keikhlasan perjuangan, agar supaya motivasinya tidak bergeser .... selain kita ikutkan workhsop-workhsop, kemarin baru pulang dari Malang dua guru ikut pelatihan entrepreneurship santri, terus kita pernah mengutus dua guru ke Jakarta dua kali untuk latihan teknisi HP Samsung, itu dua minggu,... artinya kalau toh misalnya memang diperlukan meskipun biaya sendiri kita carikan, itu biaya sendiri, lumayan,... dua guru kita kirim ke Jogja, terus ke Jakarta pelatihan IT, yang nanti insyaAllah akan menjadi instruktur BLK kita kirim ke Solo, sebelumnya satu Minggu di Surabaya....56

Dari sisi persyaratan pendidikan guru, semua guru di SMK BP Subulul Huda telah memenuhi syarat $100 \%$ karena semua telah berijazah minimal Si bahkan ada 5 guru yang telah berijazah S2. Usaha untuk meningkatkan kualitas SDM dan kualitas layanan SDM adalah dengan melakukan pemasaran internal. ${ }^{57}$ Pemasaran internal yang dilakukan di SMK BP Subulul Huda di antaranya guru SMK BP Subulul Huda secara bergantian diikutkan workshop-workshop dan pelatihan-pelatihan baik yang dilakukan dalam lingkup internal maupun eksternal. Workshop dan pelatihan yang ditujukan untuk guru-guru SMK BP Subulul Huda di antaranya pelatihan Bahasa Inggris, pelatihan entrepreneurship, pelatihan teknisi HP Samsung, pelatihan koding (pemrograman), dan lain-lain. Komitmen Kepala SMK BP Subulul Huda sangat tinggi terkait peningkatan mutu SDM dan mutu pelayanan SDM, bahkan tidak jarang pihak sekolah mengeluarkan biaya yang tidak sedikit untuk workshop dan pelatihan guru-guru SMK BP Subulul Huda. Berdasarkan pengakuan kepala SMK BP Subulul Huda tersebut, tidak hanya dari sisi ketrampilan atau keahlian profesi saja yang terus ditingkatkan, tetapi juga dari sisi rohani, yaitu setiap Selasa pada minggu terakhir dilakukan pembinaan (rohani).

Dalam pemasaran jasa, pemasaran internal sangat penting untuk dilakukan karena sumber daya manusia yang dimiliki oleh organisasi adalah orang-orang yang akan berhubungan atau berinteraksi langsung dengan pelanggan utama jasa pendidikan sehingga mereka perlu dibekali dengan ketrampilan khusus. Bahkan Edward Sallis memasukkan guru dan staf (tenaga kependidikan) sebagai pelanggan yaitu pelanggan internal ${ }^{8}$. Inilah uniknya pemasaran jasa pendidikan, di satu sisi memberikan pelayanan terhadap guru dan tenaga kependidikan merupakan satu upaya untuk mendukung keberhasilan program pemasaran organisasi dalam memberikan layanan kepada pelanggan jasa utama (peserta didik), namun disisi yang lain hal tersebut merupakan upaya organisasi untuk memberikan pelayanan terhadap pelanggan juga (pelanggan internal).

\footnotetext{
${ }^{56}$ Humaidi.

57 Wijaya, Pemasaran Jasa Pendidikan.

${ }^{8}$ Sallis, Total Quality Management In Education.
} 


\section{f. Proses (Process)}

Proses adalah semua prosedur aktual, mekanisme, dan aliran aktivitas yang digunakan untuk menyampaikan jasa ${ }^{59}$. Proses yang dimaksud dalam hal ini adalah proses penyampaian jasa dari pihak sekolah kepada pelanggan, khususnya pelanggan utama jasa pendidikan (peserta didik). Sebagaimana diketahui karakteristik jasa adalah bervariasi, maka diperlukan standar operasi khusus sebagai upaya untuk menjaga mutu penyampaian jasa pendidikan. Kegiatan belajar mengajar (KBM) di SMK BP Subulul Huda dilaksanakan pada pagi hari sedangkan kegiatan ekstrakurikuler dilaksanakan pada sore dan malam hari. Setiap hari ada pembiasaan delevering vocab bahasa Inggris kepada anak didik agar mereka mampu berbahasa Inggris. ${ }^{60}$

Selain itu, untuk meningkatkan mutu lulusan, SMK BP Subulul Huda selalu berusaha memberikan pengalaman belajar yang terbaik kepada peserta didiknya, oleh karena itu SMK BP Subulul Huda bekerja sama dengan pihak luar, termasuk bekerja sama dengan DUDI (Dunia Usaha dan Dunia Industri) khususnya untuk kegiatan prakerin (praktik kerja industri) selama minimal 6 bulan. Berikut ini adalah pernyataan kepala SMK BP Subulul Huda terkait dengan hal ini :

...terus kami kerja sama dengan DUDI, DUDI itu dunia usaha dan dunia industri, dengan Samsung, Samsung Tech Institute, jadi se-Jawa Timur itu yang punya MOU dengan Samsung itu kami, termasuk di dalamnya ada 19 (sekolah) saja di Jawa Timur....kemudian dengan BRI Syariah, jadi kita link and match, mencoba untuk nge-link ke beberapa dunia industri dan dunia usaha agar supaya nanti lulusan kami itu bisa masuk (kerja) ke mana-mana.... selain Samsung, BMD (Syariah) Dolopo... dengan BRIS/BRI Syariah Madiun, terus dengan (penyedia jasa) servisservis komputer di sekitar Madiun itu kami MOU, kan setiap tahun itu kami ada prakerin praktik kerja industri itu untuk kelas dua minimal 6 bulan, jadi anak-anak kita itu magang di beberapa dunia kerja ${ }^{61}$

Berdasarkan data di atas dapat diketahui bahwa SMK BP Subulul Huda selalu berusaha memberikan pengalaman belajar (proses) yang terbaik kepada peserta didiknya baik kegiatan di dalam sekolah maupun di luar sekolah. Kegiatan di dalam sekolah seperti proses pembiasaan delevering vocab atau pemberian kosakata bahasa Inggris setiap hari, pelatihan teknik sepeda motor, dan pemberian materi keagamaan di waktu sore dan malam hari. Kegiatan di luar sekolah di antaranya adalah prakerin (praktik kerja industri) untuk kelas XI, minimal 6 bulan magang. Proses-proses atau pengalaman-pengalaman tersebut diharapkan dapat meningkatkan mutu peserta didik.

Terkait proses lainnya yang dapat meningkatkan mutu peserta didik adalah melibatkan peserta didik menjadi kontributor akun resmi youtube, facebook, dan instagram SMK BP Subulul Huda. Tugas dan karya peserta didik dalam bidang teknologi (video, gambar/desain) yang dinilai baik dan layak dipublikasikan akan diupload di chanel youtube, facebook, dan instagram. Ditinjau dari sisi proses, hal ini sangat baik karena dapat menjadi ajang untuk melatih ketrampilan peserta didik dalam bidang teknologi dan juga dapat memotivasi peserta didik untuk berkarya.

Menurut Hermawan Kartajaya, proses menunjuk pada penciptaan customer value, yaitu bagaimana proses bisnis di dalam organisasi dijalankan dengan kualitas yang tinggi (quality), dengan harga yang serendah mungkin (cost), dan waktu penyampaian yang secepat mungkin (delivery). ${ }^{62}$ Dari beberapa aktivitas SMK BP Subulul Huda yang dijelaskan di atas, dapat diketahui bahwa strategi kepala SMK BP Subulul Huda sejalan dengan apa yang disampaikan oleh Hermawan Kartajaya khususnya dalam hal penekanan pada proses bisnis organisasi yang

\footnotetext{
${ }^{59}$ Buchari Alma dan Ratih Hurriyati, Manajemen Corporate E Strategi Pemasaran Jasa Pendidikan Fokus Pada Mutu dan Layanan Prima (Alfabeta, 2008).

${ }^{60}$ Diolah dari Dokumen Profil SMK BP Subulul Huda

${ }^{61}$ Humaidi, Wawancara.

${ }^{62}$ Kartajaya dkk., Positioning, Diferensiasi,dan Brand.
} 
berkualitas tinggi untuk menghasilkan lulusan yang berkualitas dalam rangka untuk memenuhi janji positioning yang telah ditetapkan sebelumnya.

\section{g. Bukti Fisik (Physical Evidence)}

Physical Evidence atau bukti fisik sangat penting dalam pemasaran jasa pendidikan karena salah satu karakteristik jasa adalah jasa tidak berwujud (intangibility) sehingga seorang pemasar perlu untuk menampilkan atau menunjukkan bukti fisik agar dapat memengaruhi persepsi konsumen jasa pendidikan. Bukti fisik yang berkualitas dan menarik dapat menambah nilai suatu produk (jasa pendidikan) dalam benak atau persepsi konsumen jasa pendidikan. Pernyataan tersebut sejalan dengan pernyataan Kepala SMK BP Subulul Huda, “..... masyarakat atau anak sekarang itu lebih suka melihat gebyar fisiknya.....”3

Bukti fisik yang diharapkan mampu memberikan daya tarik bagi konsumen jasa pendidikan sebagaimana yang disampaikan oleh kepala SMK BP Subulul Huda di antaranya adalah SMK BP Subulul Huda memiliki ruang kelas sendiri (ruang kelas baru), di mana pada awalnya ruang kelas masih pinjam. Selain memiliki ruang kelas, SMK BP Subulul Huda juga memiliki ruang praktik teknologi Samsung, ruang laboratorium komputer beserta komputer dengan spesifikasi tinggi, peralatan bengkel teknik sepeda motor, asrama pondok pesantren, dan tempat ibadah yang memadai. ${ }^{64}$ SMK BP Subulul Huda yang pada awal beroperasi tidak memiliki gedung, dalam waktu 3 tahun sudah memiliki gedung beserta sarana yang lengkap. Dalam pemasaran hal-hal yang terkait dengan pembangunan sarana dan prasarana dapat disebut sebagai bukti fisik. Bukti fisik sangat penting untuk menarik minat para calon peserta didik. Unsur-unsur dalam bukti fisik dapat berupa bangunan fisik, peralatan, perlengkapan, logo, warna, dan barang-barang lainnya yang disertakan dengan layanan (jasa) yang diberikan ${ }^{65}$. Sedangkan Kotler membagi bukti fisik ke dalam dua jenis, yaitu bukti penting (essential evidence) dan bukti tambahan (peripheral evidence). ${ }^{66}$ Pemenuhan kebutuhan ruang kelas, ruang praktik teknologi Samsung, ruang laboratorium komputer, bengkel teknik sepeda motor, asrama pondok pesantren, dan tempat ibadah termasuk ke dalam essential evidence.

Produk SMK BP Subulul Huda berbentuk jasa pendidikan yang salah satu karakteristiknya yaitu tidak berwujud, maka penting sekali untuk membangun persepsi konsumen agar produk (jasa) menjadi tampak berwujud. Salah satu caranya adalah dengan menunjukkan dan menampilkan bukti fisik yang berkualitas dan menarik hati konsumen, meskipun sesungguhnya bukti fisik tersebut hanya sebagai penyerta atau pendukung jasa. Parasuraman dkk, mengidentifikasi peran khusus bukti fisik, yaitu: membentuk kesan pertama, mengelola kepercayaan, memfasilitasi kualitas jasa, mengubah citra, menyediakan rangsangan indrawi, dan memasyarakatkan karyawan (tenaga pendidik dan kependidikan). ${ }^{67}$ Keputusan kepala SMK BP Subulul Huda yang memprioritaskan pemenuhan bukti fisik (bukti penting) adalah keputusan yang tepat karena betapa pentingnya peran bukti fisik untuk merebut hati (membangun persepsi) konsumen.

\section{Relevansi Strategi Pemasaran Jasa Pendidikan di SMK BP Subulul Huda Dengan Pemasaran Era Marketing 4.o}

Sebelum melakukan analisis lebih lanjut, alangkah baiknya jika peneliti menunjukkan perbandingan dan perkembangan marketing. Informasi tentang perbedaan dan perkembangan tentang marketing dapat dilihat pada tabel berikut: ${ }^{68}$

\footnotetext{
${ }^{6}$ Humaidi, Wawancara.

64 Humaidi.

${ }_{5}$ Alma dan Hurriyati, Manajemen Corporate E Strategi Pemasaran Jasa Pendidikan Fokus Pada Mutu dan Layanan Prima.

66 Wijaya, Pemasaran Jasa Pendidikan.

${ }^{6} 7$ Wijaya.

${ }^{68}$ Kotler, Kartajaya, dan Setiawan, Marketing 4.0 Bergerak Dari Tradisional ke Digital.
} 
Tabel 3. Perbandingan dan Perkembangan Marketing

\begin{tabular}{|l|l|l|l|}
\hline Marketing 1.0 & Marketing 2.o & Marketing 3.0 & \multicolumn{1}{c|}{ Marketing 4.o } \\
\hline $\begin{array}{l}\text { Berorientasi } \\
\text { pada produk. }\end{array}$ & $\begin{array}{l}\text { Berorientasi } \\
\text { pada pelanggan. }\end{array}$ & $\begin{array}{l}\text { Berorientasi } \\
\text { pada manusia. }\end{array}$ & $\begin{array}{l}\text { Berorientasi pada manusia serta } \\
\text { menggabungkan interaksi offline } \\
\text { dan online antara } \\
\text { perusahaan/lembaga dengan } \\
\text { pelanggan. }\end{array}$ \\
\hline \multicolumn{3}{|c|}{ Interaksi offline } & \multicolumn{1}{|c|}{ Interaksi Offline + online } \\
\hline
\end{tabular}

Visi SMK BP Subulul Huda merupakan pandangan ke depan yang ingin diraih oleh organisasi, yaitu : "Terwujudnya layanan pendidikan unggul berbasis pesantren mampu mencetak lulusan yang terampil, inovatif, kreatif, dedikatif, kompetitif, dan berwawasan global berbasiskan ilmu dan adab". Berdasarkan visi tersebut dapat disimpulkan bahwa SMK BP Subulul Huda ingin mencetak lulusan yang berkompeten atau berilmu dan beradab. Menurut Kotler dkk dalam Marketing 3.o, pelanggan bertransformasi menjadi manusia seutuhnya dengan pikiran, hati dan jiwa, sehingga pemasaran haruslah dapat menciptakan produk, jasa, dan kultur perusahaan/lembaga yang merangkul dan mencerminkan nilai-nilai kemanusiaan. ${ }^{69}$ Masih menurut Kotler dkk berdasarkan Stephen Sampson bahwa ada enam atribut manusia yang membuat orang lain tertarik kepada manusia lainnya, yaitu: fisik, intelektualitas, sosiabilitas, emosional, kepribadian, dan moralitas. Keenam atribut tersebut akan membentuk manusia yang utuh dan biasanya menjadi panutan. Jika berharap merek produk (jasa) agar dapat memengaruhi pelanggan sebagai teman tanpa menaklukkan mereka, maka pemasar harus mengolah keenam atribut manusia tersebut. ${ }^{\circ 0}$ SMK BP Subulul Huda telah membuka jurusan PBS dan RPL sebagai sarana untuk mencetak lulusan yang berilmu atau beradab. Secara fisik, bahwa SMK BP Subulul Huda telah menyediakan bukti fisik baik dalam bentuk sarana dan prasarana yang memadai. Secara intelektualitas, bahwa SMK BP Subulul Huda ingin mencetak lulusan yang berilmu dan terampil. Secara sosiabilitas, bahwa SMK BP Subulul Huda menyediakan saluran komunikasi kepada publik melalui berbagai media sosial seperti facebook, instagram, WhatsApp, dan youtube. Secara emosional, bahwa SMK BP Subulul Huda membuka jurusan PBS dan RPL berdasarkan kebutuhan dan keinginan segmen pasar yang dibidik. Secara kepribadian, bahwa SMK BP Subulul Huda ingin mencetak lulusan yang inovatif, kreatif, dedikatif, dan kompetitif. Secara moralitas, bahwa SMK BP Subulul Huda ingin mencetak lulusan yang beradab. Ditinjau dari enam atribut tersebut maka SMK BP Subulul Huda sudah memenuhi kriteria merek (produk/jasa) yang berorientasi pada manusia.

Sebagaimana dijelaskan pada pembahasan promosi, bahwa kegiatan promosi yang dilakukan SMK BP Subulul Huda tidak hanya mengandalkan media online dengan menggunakan website sekolah, Instagram, Youtube, dan facebook saja, namun juga melalui media offline di antaranya: forum alumni, forum wali santri, show-up ke luar, penjualan kalender ke wali santri, penyebaran brosur, mengadakan kegiatan perlombaan antar sekolah, dan melakukan personal selling ke sekolah-sekolah SMP yang sederajat di wilayah Madiun. Apa yang dilakukan oleh kepada SMK BP Subulul Huda tersebut sejatinya telah relevan dengan pemasaran pada era Marketing 4.o. Kotler dkk menjelaskan bahwa dalam ekonomi digital saat ini interaksi digital saja tidaklah cukup, oleh karena itu Marketing 4.0 merupakan pendekatan pemasaran yang menggabungkan interaksi online dan offline antara perusahaan/lembaga dan pelanggan..$^{71}$

\footnotetext{
${ }^{69}$ Kotler, Kartajaya, dan Setiawan, Marketing 4.0 Bergerak Dari Tradisional ke Digital.

${ }^{70}$ Kotler, Kartajaya, dan Setiawan.

${ }^{71}$ Kotler, Kartajaya, dan Setiawan.
} 
Kotler dkk menjelaskan ada beberapa pergeseran pemasaran tradisional ke pemasaran digital (marketing 4.0), yaitu: ${ }^{72}$

1. Dari segmentasi dan penargetan (targeting) ke konfirmasi komunitas pelanggan.

2. Dari pemosisian merek dan diferensiasi ke klarifikasi merek dari karakter dan kode.

3. Dari menjual ${ }_{4} \mathrm{P}$ ke komersialisasi ${ }_{4} \mathrm{C}$.

4. Dari proses layanan pelanggan ke pelayanan pelanggan kolaboratif.

Pertama, dari segmentasi dan penargetan ke konfirmasi komunitas pelanggan. Sebelum SMK BP Subulul Huda menentukan jurusan PBS dan RPL untuk memenuhi kebutuhan segmen pasar yang ditarget, kepala SMK BP Subulul Huda telah mengonfirmasi apa kesukaan siswa SMP IT Subulul Huda (segmen pasar yang ditarget pada awal berdirinya SMK BP Subulul Huda). Selain itu dalam promosi juga menggunakan saluran forum alumni dan forum wali santri. Hal tersebut menandakan betapa pentingnya posisi komunitas pelanggan. Kondisi seperti itu menunjukkan relasi horizontal antara merek (produk/jasa) dan pelanggan. ${ }^{73}$

Kedua, dari pemosisian merek dan diferensiasi ke klarifikasi merek dari karakter dan kode. Positioning SMK BP Subulul Huda merupakan janji yang harus dipenuhi oleh lembaga. Untuk menepati janji tersebut tidak cukup hanya sekadar menampilkan diferensiasi saja (jika dibandingkan dengan keunggulan pesaing), namun butuh bukti yang nyata. SMK BP Subulul Huda masih baru beroperasi sehingga untuk memenuhi janjinya masih membutuhkan waktu, namun setidaknya ada hal yang sudah diputuskan oleh kepala SMK BP Subulul Huda terkait dengan konsistensi karakter merek (produk/jasa), yaitu sekolah berbasis pesantren. Penolakan kepala SMK BP Subulul Huda kepada beberapa calon peserta didik yang hanya menginginkan sekolah saja tanpa harus mondok adalah salah satu konsistensi atas karakteristik merek yang ingin dibangun kepala SMK BP Subulul Huda, yaitu sekolah berbasis pesantren (SMK BP).

Ketiga, dari menjual $4 \mathrm{P}$ ke komersialisasi $4 \mathrm{C}$. $4 \mathrm{P}$ adalah product, price, place, dan promotion. Sedangkan ${ }_{4} \mathrm{C}$ adalah co-creation (menciptakan bersama), currency (mata uang), communal activation (aktivasi komunal), dan conversation (percakapan) ${ }^{74}$. Sebagaimana dijelaskan di atas, bahwa SMK BP Subulul Huda dalam menentukan produk (jurusan) PBL dan RPL mengutamakan diskusi dan konfirmasi apa kesukaan siswa SMP IT yang memang dijadikan prospek utama. Dalam ${ }_{4} \mathrm{C}$ tersebut, poin utamanya adalah pelibatan pelanggan atas hadirnya produk (jasa pendidikan), sehingga apa yang dilakukan oleh lembaga selalu berorientasi kepada pelanggan dan kebutuhannya.

Keempat, dari proses layanan pelanggan ke pelayanan pelanggan kolaboratif. Sebagaimana pada penjelasan proses, bahwa sekolah melibatkan siswa dalam proses pendidikan di SMK BP Subulul Huda, salah satunya adalah melibatkan siswa dalam mengelola konten media sosial yang dimiliki SMK BP Subulul Huda. Selain sebagai sarana untuk melatih ketrampilan siswa, kolaborasi semacam itu memang sudah menjadi tuntutan pemasaran di era marketing 4.o.

\section{Kesimpulan}

Berdasarkan data dan analisis data di atas, dapat disimpulkan bahwa strategi perencanaan pemasaran jasa pendidikan Kepala Sekolah SMK BP Subulul Huda didasari oleh kebijakan strategis Yayasan Pondok Pesantren Subulul Huda yaitu strategi pertumbuhan integrasi ke depan dalam rangka untuk menampung lulusan SMP IT Subulul Huda. Kebijakan pertumbuhan tersebut ditindaklanjuti dengan strategi pemasaran yaitu: segmentasi pasar, targeting, dan positioning. Proses segmentasi pasar dan targeting memutuskan pasar utama yang dibidik adalah alumni SMP IT Subulul Huda. Proses segmentasi dan penargetan pasar dilengkapi dengan melakukan konfirmasi kebutuhan komunitas pelanggan. Positioning yang dipilih adalah Sekolah Menengah Kejuruan yang Berbasis Pesantren (SMK BP) sebagai pencetak lulusan yang

\footnotetext{
72 Kotler, Kartajaya, dan Setiawan.

${ }^{73}$ Kotler, Kartajaya, dan Setiawan.

${ }^{74}$ Kotler, Kartajaya, dan Setiawan.
} 
terampil, inovatif, kreatif, dedikatif, kompetitif, dan berwawasan global berbasiskan ilmu dan adab. Untuk mengimplementasikan perencanaan strategis tersebut, SMK BP Subulul Huda melakukan aktivitas-aktivitas pemasaran sebagai berikut: 1) menentukan produk (jurusan/kompetensi keahlian) berdasarkan kebutuhan dan keinginan segmen pasar yang ditarget, pertimbangan diferensiasi, dan pertimbangan potensi persaingan. Berdasarkan pertimbangan tersebut, jurusan yang ditawarkan SMK BP Subulul Huda adalah jurusan Perbankan Syariah dan Rekayasa Perangkat Lunak. 2) strategi penentuan harga pada tahun pertama adalah gratis sebagai upaya memaksimalkan pangsa pasar. Sedangkan pada tahun kedua dan selanjutnya menerapkan strategi rapid-penetration strategy. 3) membangun ruang kelas dan ruang praktik siswa (place) sebagai prioritas utama dan dipercepat. Untuk mendukung percepatan tersebut, kepala SMK BP Subulul Huda menerapkan pemasaran megamarketing dengan melibatkan peran pemerintah. 4) melakukan promosi menggunakan media online dengan menggunakan web sekolah, Instagram, Youtube, dan facebook; dan juga menggunakan media offline di antaranya: forum alumni, forum wali santri, show-up ke luar, penjualan kalender ke wali santri, penyebaran brosur, mengadakan kegiatan perlombaan antar sekolah, dan melakukan personal selling ke sekolah-sekolah SMP yang sederajat di wilayah Madiun. 5) meningkatkan kualitas Sumber Daya Manusia (people) yang dimiliki SMK BP Subulul Huda dengan melakukan pemasaran internal dalam bentuk workshop atau pelatihan kepada tenaga pendidik dan kependidikan, dan memberikan pembinaan rohani secara rutin. 6) Proses pembelajaran menggunakan kurikulum nasional pada pagi hari dan kegiatan ekstrakurikuler serta kurikulum kepesantrenan pada sore dan malam hari. Proses pembelajaran juga dilakukan dengan cara pembiasaan dan peningkatan kemampuan bahasa asing (Inggris) kepada siswa setiap hari. Proses pembelajaran juga dilakukan melalui kerja sama dengan dunia usaha dan dunia industri dalam bentuk magang kerja untuk memberikan pengalaman kerja kepada siswa selama minimal 6 bulan. Selain itu, proses pembelajaran juga dilakukan dengan melibatkan siswa (kolaborasi dengan siswa) dalam pengelolaan konten media sosial milik SMK BP Subulul Huda sebagai upaya memotivasi dan melatih ketrampilan siswa dalam memanfaatkan teknologi. 7) Sebagai upaya meningkatkan nilai dan mutu sekolah, SMK BP Subulul Huda membangun tampilan fisik sekolah berupa bangunan yang indah, bersih dan nyaman (ruang kelas dan ruang praktik/laboratorium) dan melengkapi peralatan untuk kegiatan pembelajaran. Untuk memenuhi usaha tersebut, SMK BP Subulul Huda menerapkan pemasaran megamarketing (melibatkan peran pemerintah) dan juga kerja sama dengan pihak industri (salah satunya adalah Samsung). Strategi perencanaan dan implementasi pemasaran SMK BP Subulul Huda mencerminkan nilai-nilai kemanusiaan yang memenuhi enam atribut (fisik, intelektualitas, sosiabilitas, emosional, kepribadian, dan moralitas) yang menunjukkan bahwa SMK BP Subulul Huda merupakan produk/jasa yang berorientasi pada manusia. Kegiatan pemasaran SMK BP Subulul Huda juga menggabungkan interaksi online dan offline antara lembaga dan pelanggan yang merupakan keniscayaan pemasaran pada era Marketing 4.o, sehingga dapat dikatakan bahwa strategi pemasaran SMK BP Subulul Huda relevan dengan pemasaran pada era Marketing 4.0 .

\section{Daftar Pustaka}

Alma, Buchari, dan Ratih Hurriyati. Manajemen Corporate E Strategi Pemasaran Jasa Pendidikan Fokus Pada Mutu dan Layanan Prima. Alfabeta, 2008.

Fathonah, Kuni. "Strategi Pemasaran Jasa Pendidikan Dalam Meningkatkan Pelayanan Pendidikan di MAN I Sragen.” IAIN Surakarta, 2016.

Harsasi, Meirani. Pengembangan Produk. Tangerang Selatan: Universitas Terbuka, 2014. 
Humaidi, Muchtim. Wawancara, 2019.

"Kamus Besar Bahasa Indonesia (KBBI) Versi Online." Https://kbbi.web.id/taktik, t.t. Diakses 2 Juli 2019.

Kartajaya, Hermawan, Philip Kotler, Hooi Den Huan, dan Sandra Liu. Rethinking Marketing Sustainable Market-ing Enterprise di Asia. Bahasa Indonesia. Jakarta: PT. Indeks, 2005.

Kartajaya, Hermawan, Yuswohady, Jacky Mussry, dan Taufik. Positioning, Diferensiasi,dan Brand. PT Gramedia Pustaka Utama, 2004.

Kotler, Philip. Manajemen Pemasaran Jilid 1. Jakarta: PT. Prenhallindo, 1997.

___. Manajemen Pemasaran Jilid 2. Jakarta: PT. Prenhallindo, 1997.

Kotler, Philip, Hermawan Kartajaya, dan Iwan Setiawan. Marketing 4.o Bergerak Dari Tradisional ke Digital. Jakarta: PT. Gramedia Pustaka Utama, 2019.

Kotler, Philip, dan Kevin Lane Keller. Manajemen Pemasaran Jilid 1.12 ed. Jakarta Barat: PT. Indeks, 2016.

_——. Manajemen Pemasaran Jilid 2. 12 ed. Jakarta Barat: PT. Indeks, 2007.

Kurniawan, Sigit. "Memahami Marketing 4.o dalam Konteks Ekonomi Digital.” Diakses 5 September 2018. http://marketeers.com/mengenal-marketing-4-o-dalam-konteksekonomi-digital/.

Mulyasa, E. Menjadi Kepala Sekolah Profesional. Bandung: PT. Remaja Rosdakarya, 2006.

"Pendaftaran." Web Sekolah. $\quad$ Diakses 12019. http://smkbpsubululhuda.mysch.id/pendaftaran/.

"Peraturan Gubernur Nomor 22 Tahun 2017 tentang Percepatan Revitalisasi Sekolah Menengah Kejuruan di Provinsi Jawa Timur," 2017.

“Profil SMK BP Subulul Huda," 2019.

Ratnasari, Ririn Tri, dan Mastuti Aksa. Teori dan Kasus Manajemen Pemasaran Jasa. Ghalia Indonesia, 2011.

Sallis, Edward. Total Quality Management In Education. Yogyakarta: IRCiSoD, 2008.

“Sambutan Kepala Sekolah.” Web Sekolah. Diakses 1 Oktober 2019. http://smkbpsubululhuda.mysch.id.

Simamora, Bilson. Pemasaran Strategik. 1 ed. Tangerang Selatan: Universitas Terbuka, 2013.

$\begin{array}{llllll}\text { "Strategi } & \text { Samudera } & \text { Biru." }\end{array}$ https://id.wikipedia.org/wiki/Strategi_samudera_biru.

Suparyanto, RW, dan Rosad. Manajemen Pemasaran Dilengkapi 45 Judul Penelitian dan Kasus sehari-hari di Indonesia. Bogor: In Media, 2015. 
Taufik, Fatkhurohman. "SMA dan SMK yang Sepi Peminat, Ini yang Akan Dilakukan Pemerintah." Berita. $\quad$ Suarasurabaya.net, $11 \quad$ Juli 2017. https://www.suarasurabaya.net/kelanakota/2017/SMA-dan-SMK-yang-Sepi-PeminatIni-yang-Akan-Dilakukan-Pemerintah/.

Widjajanti, Chrismi, Amat Mukhadis, Andika Bagus Nur Rahma Putra, Ahmad Mursyidun Nidhom, Ahmad Dardiri, dan Hary Suswanto. Panduan Sinkronisasi Bidang Keahlian Di SMK Dengan Prioritas Potensi Unggulan Wilayah Dan Tenaga Kerja. Direktorat Pembinaan Sekolah Menengah Kejuruan, Direktorat Jenderal Pendidikan Dasar dan Menengah, Kementerian Pendidikan dan Kebudayaan RI, 2017.

Wijaya, David. Pemasaran Jasa Pendidikan. Jakarta: Salemba Empat, 2012. 